\title{
Northern distributional extensions of Peropteryx leucoptera and Peropteryx pallidoptera (Chiroptera: Emballonuridae) from Vichada, Colombia
}

\author{
Miguel E. Rodríguez-Posada1*(i) , Camilo Fernández-Rodríguez 1id , Polidoro \\ Sandoval ${ }^{1}$
}

1 Fundación Reserva Natural La Palmita, Centro de Investigación. Grupo de investigaciones territoriales para el uso y conservación de la biodiversidad, Bogotá, Colombia.

*Correspondencia: director.cientifico@lapalmita.com.co

\section{Resumen}

El murciélago cara de perro de alas blancas (Peropteryx leucoptera) y el murciélago cara de perro de alas pálidas (Peropteryx pallidoptera) se diferencian de otros murciélagos embalonúridos porque tienen las alas blancas o translucidas. Su distribución y biología son poco conocidas porque no son capturados usualmente con redes de niebla en inventarios tradicionales. En esta contribución, ampliamos la distribución conocida de $P$. leucoptera $260 \mathrm{~km}$ al noreste y la de $P$. pallidopera $290 \mathrm{~km}$ al noroeste. Nuestros registros son de tres especímenes recolectados en un inventario en el corredor ripario del río Meta en el departamento del Vichada. Esta localidad, es el límite norte de la distribución de ambas especies. Es necesario continuar el trabajo de campo e inventarios de mamíferos con recolección de especímenes a lo largo de la región de los Llanos. llamamos la atención sobre la importancia de los troncos caidos como refugio de $P$. leucoptera y otras especies poco conocidas de murciélagos neotropicales.

Palabras clave: ecosistemas de sabanas, mamíferos, murciélagos de cola envainada, murciélagos de sacos alares, Orinoquía.

\section{Abstract}

The White-winged Dog-like Bat (Peropteryx leucoptera) and the Pale-winged Dog-like Bat (Peropteryx pallidoptera) are distinguished from the other emballonurid bats because they have white or translucent wings. Their distribution and biology are poorly known due to they are not usyally captured in traditional bat inventories using mist nets. In this contribution, we extend the known distribution of P. leucoptera $260 \mathrm{~km} \mathrm{NE}$ and P. pallidoptera $290 \mathrm{~km} \mathrm{NE}$. Our records are from three specimens collected in a mammal assessment at the riparian corridor of the river Meta in the Vichada department. This locality is the northern limit of the distributional range of both species. We highlight the need to continue the fieldwork on mammals inventories with specimen collections through the Colombian Llanos. We call attention to the importance of horizontal rotten logs as roost of $P$. leucoptera and other little known neotropical bats.

Keywords: mammals, Orinoquia, sac-winged bats, savanna ecosystems, sheath-tailed bats. 
The Dog-like bats of the genus Peropteryx Peters 1867 are widely distributed in the

The Dog-like bats of the genus Peropteryx Peters, 1867 are widely distributed in the lowlands of the Neotropics. The genus contains five recognized species (Bonaccorso 2019): P. macrotis (Wagner 1843); P. kappleri Peters, 1867; P. trinitatis Miller, 1899; P. leucoptera Peters, 1867 and P. pallidoptera Lim, Engstrom, Reid, Simmons, Voss, \& Fleck, 2010. These bats are small to medium-sized emballonurids (forearm 38-54 $\mathrm{mm}$ ) and differ from other species of the family Emballonuridae because they have a small wing sac located in the leading edge of the antebrachial membrane, the skull has an expanded rostrum an undivided basisphenoid pit without a medial septum, and a spicule-like anterior upper premolar (Hood \& Gardner 2008).

Among Peropteryx species, $P$. leucoptera and $P$. pallidoptera are distinguishable because they have translucent or white wings. These species were previously confused among them, and their distribution and biology are poorly known due to they are no commonly captured in traditional bat inventories using mist nets (Lim et al. 2010; McDonough et al. 2010). The current distribution of $P$. leucoptera comprises French Guiana, Guyana, Suriname, Venezuela, Colombia, Peru, Brazil, and Ecuador, where it inhabits tropical rainforest and riparian forest in savannas (Suarez-Castro et al. 2012; Mikalauskas et al. 2014). In Colombia, $P$. leucoptera has been reported from a riparian forest of savanna ecosystems in the Colombian Llanos and lowland tropical rainforest of La Macarena mountains, in the departments of Meta and Casanare (Suárez-Castro et al. 2012; Mantilla-Meluk et al. 2014). On the other hand, P. pallidotera is known from Ecuador, Peru, Brazil, and Colombia, where inhabits the Amazonian tropical rainforests and riparian forest in savanna ecosystems in the Colombian Llanos (Lim et al. 2010; McDonough et al. 2010; Suárez-Castro et al. 2012; Morales-Martínez 2013). In Colombia, P. pallidoptera is known from the east versant of the Andes in the Caquetá department in a transitional forest between the Amazon and Andean regions, and from riparian forests of the Colombian Llanos in the Meta department (Suárez-Castro et al. 2012; Morales-Martínez 2013; Mantilla-Meluk et al. 2014).

During a mammal's rapid assessment in the floodplain forest of the Meta river in the Vichada department, we recorded three bats identified as $P$. leucoptera and P. pallidopera. Here, we report these records that significantly extend the range of distribution of both species.

The mammal's rapid assessment was conducted in June 2017 during the rainy season at La

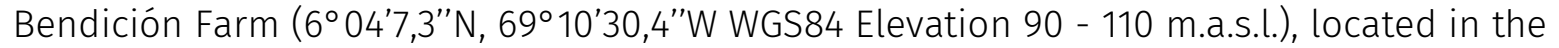
north of the Vichada department (Figure 1). This locality is in the Llanos ecoregion, in the Tropical and subtropical grasslands, savannas, and shrublands Biome (Dinerstein et al. 2017), and the flat high plain savannas ecosystem (Romero-Ruiz et al. 2010). The area comprises the riparian corridor of the Meta River. Sampled habitats comprise: 1. Meta river's floodplain forest, 2. gallery forest of streams that empty into the Meta river, and 3. open savannas with spread shrubs. The weather is mega-thermal and wet, the mean temperature varies between 27 and $28^{\circ} \mathrm{C}$. Seasonality of precipitation is monomodal with two seasons, the dry season is between December and March and the wet between April and November, with annual precipitation between 2.000 and $2.500 \mathrm{~mm}$, and the wettest month is June (Minorta-Cely \& Rangel-Ch 2014). 


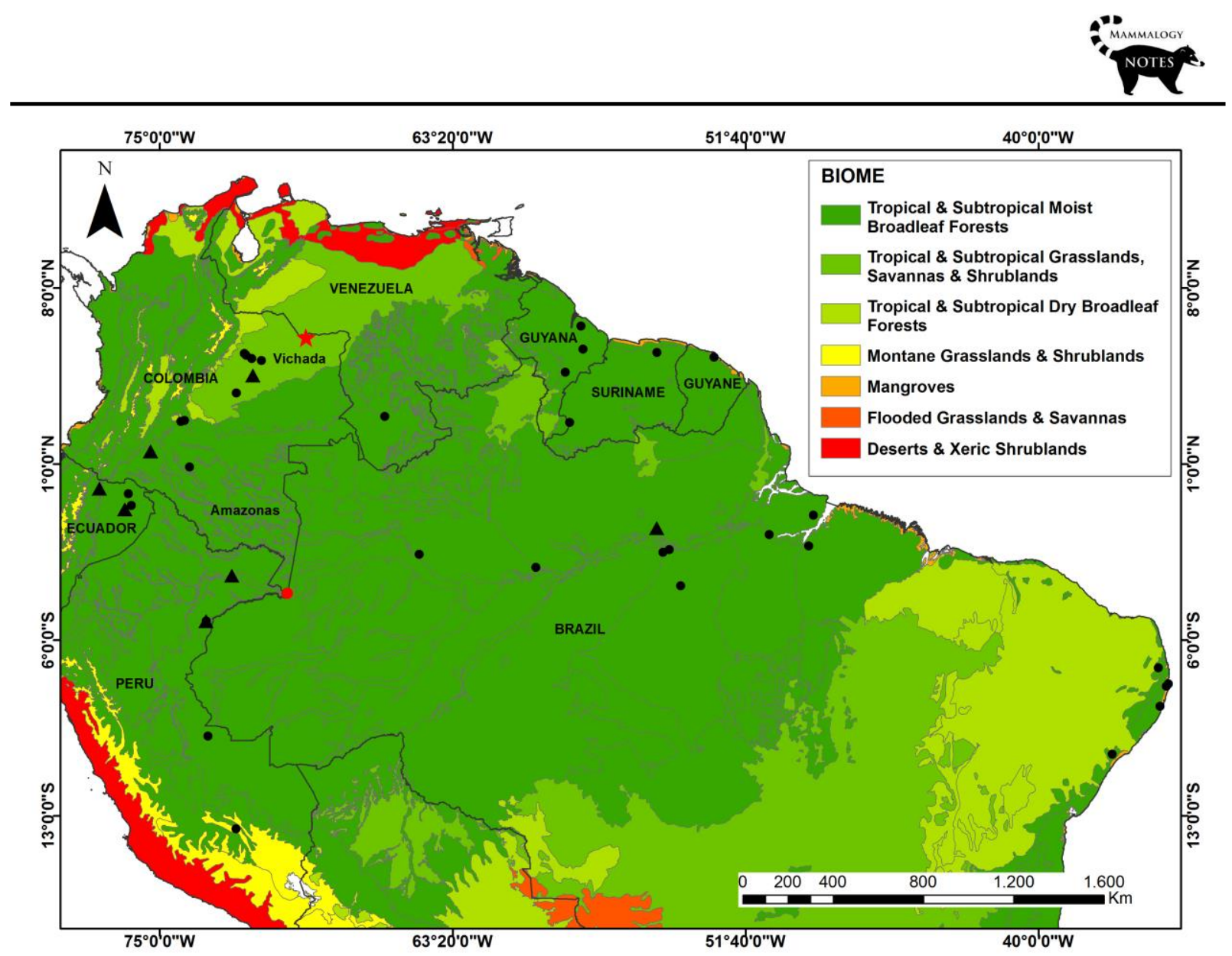

FIGURE 1. Geographic distribution of Peropteryx leucoptera (black circles) and Peropteryx pallidoptera (black triangles). New records (red star) in the La Bendición farm, in the municipality of La Primavera, department of Vichada, and (red circle) indigenous community Hitoma in the municipality of Leticia, department of Amazonas. For other records, see McDonough et al. (2010), Suárez-Castro et al. (2012), Morales-Martínez (2013), Mikalauskas et al. (2014).

Bats were caught using mist nets at ground level. The nets were opened before sunset and closed after midnight (17h00 - 00h00). We had a sampling effort per night of 288 meters per night per hour (m.n.h) and a total sampling effort of 1.152 m.n.h. All captured bats were handled based on the animal care and guidelines of the American Society of Mammalogists (Sikes et al. 2016). We checked captured bats for identification, sex, and reproductive status. We preserved almost one voucher specimen per species, fixed in $10 \%$ formalin, and preserved in $90 \%$ ethanol to confirm the identification and build a reference collection. Collected bats were euthanized using the thoracic compression procedure (Sikes et al. 2016). We took tissue samples and preserved these in $96 \%$ ethanol. We extracted and cleaned the specimen's skulls using dermestids. The specimens were processed and deposited in the collection of Mammals "Alberto Cadena García" of Instituto de Ciencias Naturales, Universidad Nacional de Colombia (ICN). Specimens were collected under a research license as per Resolution No 500.41-16-0884 dated July 19th, 2016 granted by CORPORINOQUIA.

We based the P. leucoptera records on two females (ICN 24290, 24291). ICN 24290 is a juvenile with no completely ossified phalanx and translucent dactylopatagium, and the ICN 24291 was lactating. Our specimens coincide in all characteristics with previous descriptions of P. leucoptera (Hood \& Gardner 2008; Lim et al. 2010; Suarez-Castro et al. 
2012): Wings white beyond of forearm and attached to the inferior extremities at the metatarsals. Ears joined above the forehead with a band of skin. The skull has a basisphenoid pit deep, with two large and deep lateral pterygoid pits (Figure $2 \mathrm{a}-2 \mathrm{c}$ ). Skull measurements are in the known range (Table 1). We captured these specimens in a net installed next to a horizontal rotten log (length $=3 \mathrm{~m} \times$ high $=1,5 \mathrm{~m}$ ), near a creek in the floodplain forest. We observed three additional bats, apparently of the same species, at the interior of the same horizontal rotten log but we were unable to catch them.

We based the P. pallidoptera record on one female (ICN 24292). Our specimen coincides in all characteristics with previous descriptions of P. pallidotera (Lim et al. 2010): Ears separated. Translucent wings (plagiopatagium, dactylopatagium, and propatagium) attached to the inferior extremities at the ankle. The skull has the lateral pterygoid pits small and separated by a mesopterygoid extension between them (Figure $2 d-2 f$ ). The skull measurements are in the known range. (Table 1). This specimen was capture using mist-nets at one side of a stream in the gallery forest.

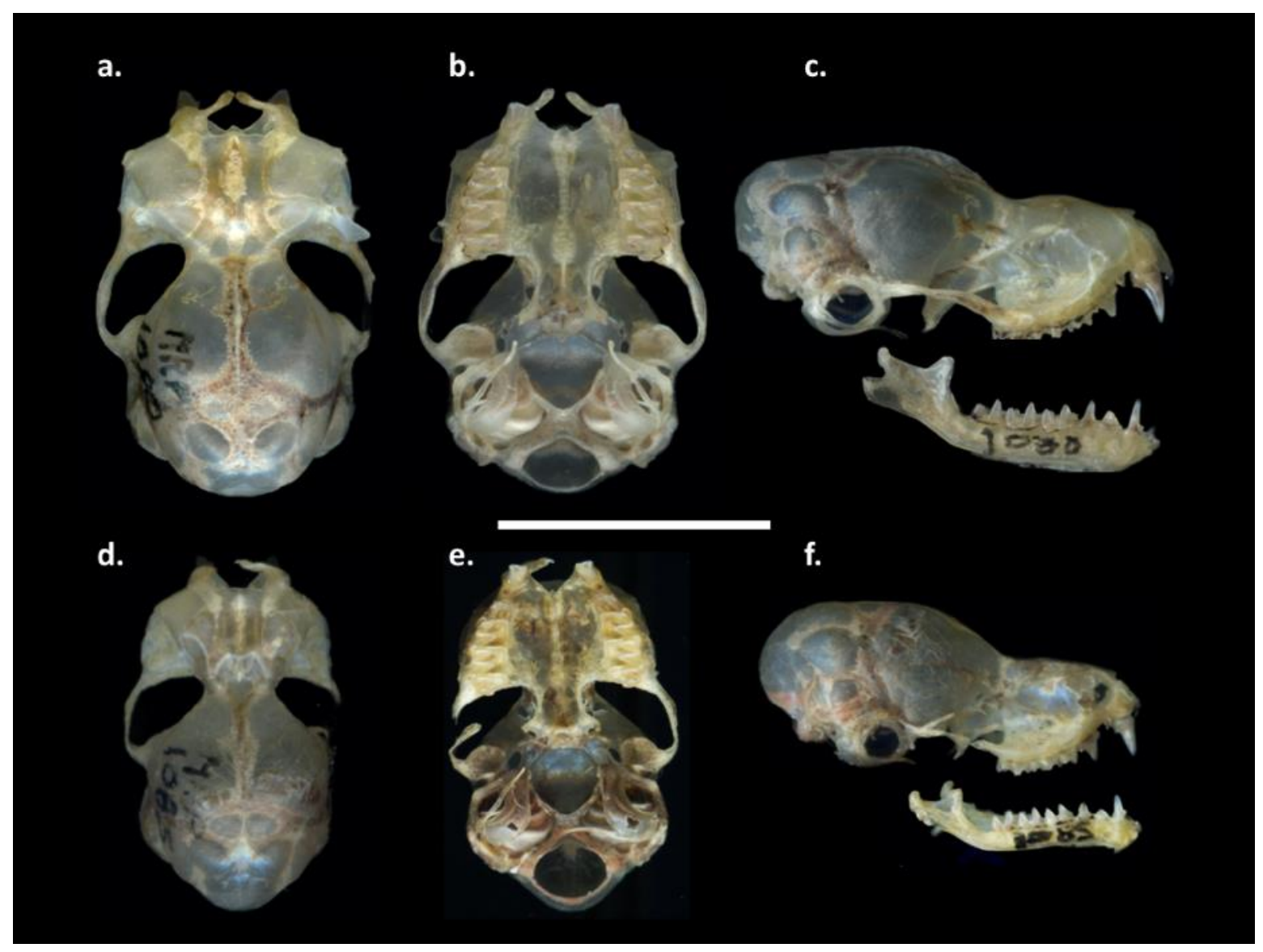

FIGURE 2. Dorsal (a) and ventral (b) views of skull and lateral view of skull and mandible (c) of Peropteryx leucoptera (ICN 24291 ), and dorsal (d) and ventral (e) views of skull and lateral view of skull and mandible (f) of Peropteryx pallidoptera (ICN 24292). Scale bar $=10 \mathrm{~mm}$.

Our records extend the known distribution ranges of $P$. pallidoptera $290 \mathrm{~km} \mathrm{NE}$ (MoralesMartínez 2013) and P. leucoptera 260 km NE (Suárez-Castro et al. 2012), comprising the current northern limit of the distributional range of both species (Bonaccorso 2019). Additionally, these records are the first reports of both species for the Vichada department 
(Solari et al. 2013; Mosquera-Guerra et al. 2017). Our records suggest that these species could be distributed along riparian forests in the Orinoco Llanos as Mantilla-Meluk et al. (2014) suggested in their potential distribution models of emballonurid species in Colombia.

The bat fauna of the Colombian Llanos has been considered little diverse (RodriguezMahecha et al. 2005; Mantilla-Meluk et al. 2009; 2014), but recent studies on bat assemblages (Estrada-Villegas \& Ramírez 2013; Morales-Martínez et al. 2018) and new records of bat species in the region (Calderón-Capote et al. 2016; Rodriguez-Posada et al. 2017), draw attention to a potential higher diversity, underestimated by the low number of studies in the region.

TABLE 1. Skin and skull measurements (in $\mathrm{mm}$ ) and weight (in grams) of specimens of Peropteryx leucoptera and Peropteryx pallidoptera reported in this study. *Range of each species reported by Lim et al. (2010), McDonough et al. (2010), Suárez-Castro et al. (2012), and Morales-Martínez (2013). Measurements were taken according to Lim et al. (2010) and McDonough et al. (2010).

\begin{tabular}{|c|c|c|c|c|c|c|c|c|c|c|}
\hline \multirow[t]{3}{*}{ Measurements } & \multicolumn{7}{|c|}{ Peropteryx leucoptera } & \multicolumn{3}{|c|}{ Peropteryx pallidoptera } \\
\hline & \multirow{2}{*}{$\begin{array}{c}\text { ICN } \\
24290 \\
\text { female } \\
\end{array}$} & \multirow{2}{*}{$\begin{array}{c}\text { ICN } \\
24291 \\
\text { female } \\
\end{array}$} & \multirow{2}{*}{$\begin{array}{c}\text { YMS } \\
708 \\
\text { female }\end{array}$} & \multirow{2}{*}{$\begin{array}{c}\text { YMS } \\
709 \\
\text { female }\end{array}$} & \multirow{2}{*}{$\begin{array}{c}\text { YMS } \\
711 \\
\text { male } \\
\end{array}$} & \multicolumn{2}{|c|}{$\begin{array}{l}\text { range from } \\
\text { literature* }\end{array}$} & \multirow{2}{*}{$\begin{array}{c}\text { ICN } \\
24292 \\
\text { female } \\
\end{array}$} & \multicolumn{2}{|c|}{$\begin{array}{l}\text { range from } \\
\text { literature* }\end{array}$} \\
\hline & & & & & & males & female & & male & female \\
\hline Mass & 5 & 8 & 8 & 8 & 7,5 & - & - & 5 & - & - \\
\hline Total length & 60 & 74 & 66 & 68 & 69 & $56-69$ & $54-82$ & 58 & $54-62$ & $52-67$ \\
\hline Tail & 10 & 12 & 11 & 13 & 13 & $5-16$ & $12-17$ & 13 & $11-15$ & $11-14$ \\
\hline Hind Foot & 9 & 8 & 7 & 8 & 8 & $7-10$ & $7-10$ & 8 & $7-9$ & $8-10$ \\
\hline Ear & 19 & 21 & 15 & 18 & 15 & $13-20$ & $15-19$ & 16 & $13-15$ & $14-17$ \\
\hline Forearm length & 40,9 & 45,2 & 45,6 & 46,9 & 43,9 & $39-46$ & $42-46,4$ & 38,9 & $39-42$ & $37-43$ \\
\hline Greatest length of skull & - & 15,55 & 16,44 & 16,5 & 15,87 & $14,9-15,6$ & 16,1 & 13,41 & $13,6-14,1$ & $13,6-14,1$ \\
\hline Condyloincisive length & - & 14,63 & 14,91 & 15 & 14,89 & $13,8-14,5$ & 14,7 & 12,45 & $12-12,5$ & $12,2-12,8$ \\
\hline Condyle canine length & - & 14 & 14,33 & 14,51 & 14,41 & - & - & 11,92 & - & - \\
\hline Zygomatic breadth & - & 10,2 & 10,14 & 10,21 & 10,58 & $9,3-9,6$ & 10,1 & 8,07 & $8,1-8,2$ & $7,9-8,7$ \\
\hline Mastoid breadth & - & 8,27 & 7,98 & 7,89 & 8,11 & $7,6-8,0$ & 8,0 & 7,04 & $7,1-7,3$ & $6,9-7,4$ \\
\hline Breadth of braincase & - & 7,25 & 7,18 & 7,15 & 7,07 & $6,8-7,3$ & 7,4 & 6,24 & $6,3-6,5$ & $6,2-6,7$ \\
\hline $\begin{array}{l}\text { Post orbital constriction } \\
\text { breadth }\end{array}$ & - & 3,64 & 3,46 & 3,3 & 3,23 & $3,1-3,6$ & 3,4 & 2,6 & $2.2-2.9$ & $2,4-2,9$ \\
\hline Maxillary toothrow & - & 6,48 & 6,77 & 6,77 & 6,66 & $6,1-6,4$ & 6,6 & 5,3 & $5,0-5,4$ & $5,0-5,5$ \\
\hline $\begin{array}{l}\text { Breadth across upper mo- } \\
\text { lars }\end{array}$ & - & 7,51 & 7,38 & 7,32 & 7,88 & $6,7-7,0$ & 7,5 & 6 & $5,8-5,9$ & $5,7-6,4$ \\
\hline $\begin{array}{l}\text { Breadth across upper ca- } \\
\text { nines }\end{array}$ & - & 4,24 & 4,26 & 4,28 & 4,27 & - & - & 3,22 & - & - \\
\hline
\end{tabular}

The knowledge about mammals in the Orinoco Llanos is low due to the sampling is small and disperse geographically and temporally with spread inventories in specific localities (Ferrer-Pérez et al. 2009; Trujillo et al. 2010). Even though the Llanos region has continuous oil exploitation, there are plenty of environmental impact studies with information about mammals, unfortunately, this information is hard to access, and their quality is uncertain (Trujillo et al. 2010; Gómez-Sandoval et al. 2017). Then, we highlight the urgent need to increase the study and to inventory biodiversity along this extensive natural region, which comprises $30,4 \%$ of the Colombian territory.

Additionally, we report three $P$. leucoptera specimens captured in a primary rainforest within a fallen trunk (collected by Yaneth Muñoz-Saba, field numbers YMS 708, 709, 711, 
deposited at ICN but uncatalogued) from the indigenous community Hitoma (Figure 1), in the municipality of Leticia, department of Amazonas ( $4^{\circ} 08^{\prime} \mathrm{S}, 69^{\circ} 55^{\prime} \mathrm{W}$ WGS84 Elevation 82 m.a.s.l.). These records fill a gap in the previously known distribution of P. leucoptera in the Amazon region (Mikalauskas et al. 2014). Our records and other P. leucoptera reports suggest that this species is strongly associated to use dark horizontal chambers of horizontal rotten logs (Simmons \& Voss 1988; Mikalauskas et al. 2014). It calls attention to the importance of fallen tree trunks as the main roost resource for $P$. leucoptera and other neotropical bats, mainly emballonurids. This represents an opportunity to focus research on the ecology and natural history of little-known bat species.

\section{ACKNOWLEDGMENTS}

We thank the Fundación Reserva Natural La Palmita, Research Center for administrative, technical, and logistical support. CORPORINOQUIA awarded the specimens collection license: resolution No 500.41-16-0884 dated 19 July 2016. We are especially thankful to Hugo López-Arevalo for permitting us to study the specimens under their care in the ICN mammal collection. We thank Daniela Martinez Medina who reviewed an early version of the manuscript.

\section{REFERENCES}

Bonaccorso F. 2019. Family Emballonuridae. In : Wilson DE, Mittermeier RA, editors. Handbook of the Mammals of the World. Volumen 9, Bats. Lynx Edicions. Barcelona. p. 334-373.

Calderón-Capote MC, Morales-Martínez DM, Fernández-Rodríguez C, Rodríguez-Posada ME. 2016. First confirmed records of rare Short-eared Bat, Cyttarops alecto Thomas, 1913 (Chiroptera: Emballonuridae), from the Orinoco Llanos of Colombia. Check List 12(5):1-5. https:// doi.org/10.15560/12.5.1980

Dinerstein E, Olson D, Joshi A, Vynne C, Burgess ND, Wikramanayake E, Hahn N, Palminteri S, Hedao P, Noss R, et al. 2017. An Ecoregion-Based Approach to Protecting Half the Terrestrial Realm. BioScience. 67(6):534-545. https://doi.org/10.1093/biosci/bix014

Estrada-Villegas S, Ramírez BH. 2013. Bats of Casanare, Colombia. Chiroptera Neotropical. 19:1-13.

Ferrer-Pérez A, Beltrán M, Díaz-Pulido AP, Trujillo F, Mantilla-Meluk H, Herrera O, Alonso AF, Payán E. 2009. Lista de los mamíferos de la cuenca del Río Orinoco. Biota Colombiana 10:179-207.

Gómez-Sandoval PA, Mojica-Corzo JI, Mejía-Egas O. 2017. Trazabilidad de los registros de mamíferos en el marco del otorgamiento de licencias ambientales para proyectos de hidrocarburos en Colombia. Revista de la Academia Colombiana de Ciencias Exactas Físicas y Naturales 41:5158. http:/ / dx.doi.org/10.18257/ raccefyn.439

Hood C, Gardner AL. 2008. Family Emballonuridae Gervais, 1856. In: Gardner AL, editor. Mammals of South America, Volume 1, Marsupials, Xenarthrans, Shrews and Bats. The University of Chicago Press. p. 188-207.

Lim B, Engstrom MD, Reid FA, Simmons NB, Voss RS, Fleck DW. 2010. A new species of Peropteryx (Chiroptera: Emballonuridae) from western Amazonia with comments on phylogenetic relationships within the genus. American Museum Novitates 3686:1-20.

Mantilla-Meluk H, Jiménez-Ortega AM, Baker R.J. 2009. Phyllostomid bats of Colombia: annotated checklist, distribution, and biogeography. Special Publications, Museum of Texas Tech University 56:1-44. 
Mantilla-Meluk H., Ramírez-Chaves HE, Jiménez-Ortega AM, Rodríguez-Posada ME. 2014. Emballonurid bats from Colombia: Annotated checklist, distribution, and biogeography. Therya. 5(1): 229-255.

McDonough MM, Lim BK, Ferguson AW, Brown CM, Burneo SF, Ammerman LK. 2010. Mammalia, Chiroptera, Emballonuridae, Peropteryx leucoptera Peters, 1867 and Peropteryx pallidoptera Lim, Engstrom, Reid, Simmons, Voss and Fleck, 2010: Distributional range extensions in Ecuador. Check List 6(4):639-643.

Mikalauskas JS, da Rocha PA, Dias D, Peracchi AL. 2014. Update on the distribution of Peropteryx leucoptera Peters, 1867 (Mammalia, Chiroptera, Emballonuridae): First record for the state of Sergipe, northeastern Brazil. Check List 10(2):402-406.

Minorta-Cely V, Rangel-Ch JO. 2014. El clima de la Orinoquia colombiana. In: Rangel-Ch JO, editor. Colombia Diversidad Biótica XIV La región de la Orinoquia de Colombia. pp: 207-236.

Morales-Martínez DM. 2013. Primer registro de Peropteryx pallidoptera (Chiroptera: Emballoniridae) en ecosistemas de Sabana. Therya 4(2):401-407. http:/ / doi.org/10.12933/therya-13-134

Morales-Martínez DM, Rodríguez-Posada ME, Fernández-Rodríguez C, Calderón-Capote MC, Gutiérrez-Sanabria D. 2018. Spatial variation of bat diversity between three floodplainsavanna ecosystems of the Colombian Llanos. Therya 9:41-52. http:// doi.org/10.12933/therya-18-537

Mosquera-Guerra F, Trujillo F, Mantilla-Meluk H, Diaz-Pulido A. 2017. Mamíferos. In: Trujillo F, Lasso CA, editors. IV. Biodiversidad del río Bita. Vichada, Colombia. Serie Editorial Fauna Silvestre Neotropical. Instituto de Investigación de Recursos Biológicos Alexander von Humboldt (IAvH), Bogotá. P. 305-343.

Rodríguez-Mahecha JV, Alberico M, Trujillo F, Jorgenson J (editors). 2005. Libro rojo de los mamíferos de Colombia. Serie Libros Rojos de Especies Amenazadas de Colombia. Conservación Internacional Colombia, Instituto de Ciencias Naturales -Universidad Nacional de Colombia, Ministerio del Medio Ambiente. Bogotá, Colombia.

Rodríguez-Posada ME, Fernández-Rodríguez C, Morales-Martínez DM, Calderón-Capote MC. 2017. First record of De Vivo's Disk-winged Bat, Thyroptera devivoi Gregorin, Gonçalves, Lim \& Emstrong, 2006 (Chiroptera, Thyropteridae), from Colombia, with comments about the record of Thyroptera lavali Pine, 1993 from country. Check List 13(4):355-361. https:// doi.org/10.15560/13.4.355

Romero-Ruíz M, Etter A, Sarmiento A, Tansey K. 2010. Spatial and temporal variability of fires in relation to ecosystems, land tenure and rainfall in savannas of northern South America. Global Change Biology 16:2013-2023. https:// doi.org/10.1111/j.1365-2486.2009.02081.x

Sikes RS, Animal Care and Use Committee of the American Society of Mammalogists. 2016 Guidelines of the American Society of Mammalogists for the use of wild mammals in research and education. Journal of Mammalogy 97:663-688. https:// doi.org/10.1093/jmammal/gyw078

Simmons NB, Voss RS. 1998. The mammals of Paracou, French Guiana: A Neotropical lowland rainforest fauna. Part 1. Bats. Bulletin of the American Museum of Natural History 237: 1-219.

Solari S, Muñoz-Saba Y, Rodríguez-Mahecha JV, Defler TR, Ramírez-Chaves HE, Trujillo F. 2013. Riqueza, endemismo y conservación de los mamíferos de Colombia. Mastozoología Neotropical 20:301-365.

Suárez-Castro A, Ramírez-Chaves HE, Rodríguez-Posada ME, García J. 2012. New records of Peropteryx leucoptera and first record of Peropteryx pallidoptera (Chiroptera. Emballonuridae) from Colombia. Mastozoología Neotropical 19:165-171. 
Trujillo González F, Beltrán Gutiérrez M, Díaz-Pulido A, Ferrer Pérez A, Payan Garrido E. 2010. Mamíferos. Capítulo 10. In: Lasso CA, Usma JS, Trujillo F, Rial A, editors. Biodiversidad de la Cuenca del Orinoco: bases científicas para la identificación de áreas prioritarias para la conservación y uso sostenible de la biodiversidad. Instituto de Investigación de Recursos Biológicos Alexander von Humboldt, WWF Colombia, Fundación Omacha, Fundación La Salle e Instituto de estudios de la Orinoquia (Universidad Nacional de Colombia). Bogotá, D. C., Colombia. p. 311-334.

Editor: José F. González-Maya

Recibido: 2020-10-08

Revisado: 2020-11-20

Aceptado: 2020-12-06

Publicado: 2021-05-24 